\title{
Supplementation of Nafural Tannins as an Alternative to Formaldehyde in Urea and Melamine Formaldehyde Resins used in MDF Production
}

\section{Dodatak prirodnih tanina kao alternativa formaldehidu u urea-formaldehidnim i melamin-formaldehidnim ljepilima u proizvodnji MDF ploča}

\author{
Original scientific paper • Izvorni znanstveni rad \\ Received-prispjelo: 23. 4. 2017. \\ Accepted-prihvaćeno: 13 . 6. 2018. \\ UDK: $630 * 813.111 ; 630 * 824.328 ; 630 * 863.312$ \\ doi:10.5552/drind.2018.1726
}

\begin{abstract}
The aim of this study was to evaluate some mechanical and physical properties of medium density fiberboards $(M D F)$ made from different adhesive types. Five panel types were made from mixtures of tannin $(T)$ to urea formaldehyde (UF) and tannin to melamine formaldehyde (MF), TUF ${ }_{10 \%}, T U F_{20 \%}, M F, T M F_{10 \%}$ and $T M F_{20 \%}$, respectively. Besides, the effect of press temperatures $\left(170\right.$ and $\left.180^{\circ} \mathrm{C}\right)$ on the curing of the formulations was studied. Some mechanical properties (modulus of rupture, modulus of elasticity and internal bond strength), physical properties (thickness swelling and water absorption) and formaldehyde emission of the resulting panels were determined. The incorporation of tannin decreases the formaldehyde emission of the panels. However, flexural properties and internal bond strength decreased with increasing tannin ratio. The results indicated that panels can be manufactured using tannin up to $10 \%$ in UF resin without falling below the minimum EN Standard requirements of mechanical properties for general purpose MDF panels.
\end{abstract}

Key words: Tannin, MF, UF, Formaldehyde emission, $M D F$

SAŽETAK • Cilj rada bio je procijeniti određena mehanička i fizikalna svojstva ploča vlaknatica srednje gustoće (MDF ploča) proizvedenih primjenom različitih vrsta ljepila. Pet vrsta ploča proizvedeno je uz primjenu smjese tanina (T) i urea-formaldehidne smole (UF) te tanina i melamin-formaldehidne smole (MF) u različitim omjerima, označenih kao TUF10\%, TUF20\%, MF, TMF10\% i TMF20\%. Osim toga, proučavan je utjecaj temperature prešanja $\left(170 \mathrm{i} 180^{\circ} \mathrm{C}\right)$ na otvrdnjavanje tako dobivenih smjesa ljepila. Upoznata su i neka mehanička svojstva

\footnotetext{
Authors are Ph.D. student and professor at Department of Wood and Paper Science and Technology, Natural Resources Faculty, University of Tehran, Iran. ${ }^{2}$ Author is professor at Wood Science \& Technology Department, Faculty of Civil Engineering, Shahid Rajaee Teacher Training University (SRTTU), Tehran, Iran. ${ }^{3}$ Author is research director at Shafarood institution of forest research and management, Gilan, Iran. Autori su doktorand i profesor Odjela za znanost i tehnologiju drva i papira, Fakultet prirodnih resursa, Sveučilište u Teheranu, Teheran, Iran. ${ }^{2}$ Autor je profesor Odjela za znanost i tehnologiju drva, Građevinski fakultet, Učiteljsko sveučilište Shahid Rajaee (SRTTU), Teheran, Iran.

${ }^{3}$ Autor je znanstvenik Shafarood institucije za istraživanje i upravljanje šumama, Gilan, Iran.
} 
proizvedenih MDF ploča (modul loma, modul elastičnosti i čvrstoća raslojavanja), njihova fizikalna svojstva (bubrenje u debljinu i upijanje vode) te emisija formaldehida. Uz dodatak tanina proizvedene ploče imaju manju emisiju formaldehida. Međutim, čvrstoća na savijanje i čvrstoća raslojavanja tih ploča smanjuju se s povećanjem udjela tanina u ljepilu. Rezultati su pokazali da ploče mogu biti proizvedene s ljepilima u kojima je urea-formaldehidnim smolama dodano do $10 \%$ tanina a da ploče i dalje udovoljavaju minimalnim EN standardnim zahtjevima mehaničkih svojstava za MDF ploče opće namjene.

Ključne riječi: tanin, $M F, U F$, emisija formaldehida, $M D F$

\section{INTRODUCTION}

\section{UVOD}

Over the past few decades, as a result of environmental awareness, the problem of air pollution in residential buildings increased more and more concerns on indoor air pollutants such as formaldehyde and acetaldehyde to be released from building materials and products. The release of formaldehyde from the panels used for internal applications is one of the main factors that cause sick building syndrome known indoor. Thus, the problem of formaldehyde emissions is one of the most important aspects of research of urea formaldehyde resin that should be seriously and thoroughly investigated and studied. On the other hand, the demand for wood composites such as medium density fiberboard, oriented strand board (OSB), plywood, hardboard and veneer products has recently increased significantly all over the world (Pirayesh and Saadatnia, 2015). Solving old and new challenges and movement towards green chemistry will require human unity and creativity. A new approach will also be needed to make better and greater use of renewable resources, and increase the resilience and diversity of production systems (Salari et al., 2013). A selection of bio wastes including wheat straw, sugarcane, sunflower seed hull, bamboo and palm have been successfully used in panel manufacturing and are already in the market under different trade names (Buyuksari et al., 2010).

Urea formaldehyde resin is the most important type of adhesive for manufacturing wood based composites (Kim and Kim, 2005; Nemli et al., 2008 ). Low price, good technological properties, absence of colors in cured polymer and easiness of application for a variety of curing conditions are the advantages of urea formaldehyde, while, formaldehyde emission and poor water resistance are its main disadvantages (Abdolzadeh et al., 2011; Papadopoulos and Hague, 2003). With rising economic standards, concerns about human health and the environment have been raised due to the increasing demand for wood based panels (Habibi, 2008). Formaldehyde ( $\mathrm{HCOH})$ is a suspected human carcinogen that is known to be released from pressedwood products used in home construction, including products made with urea-formaldehyde (UF) resins (Khanjanzadeh et al., 2013). Formaldehyde has also been found to produce nasal carcinomas in mice and rats after exposure to 14.1 and $5.6 \mathrm{ppm}$ of formaldehyde, respectively, over a long period of time (Khanjanzadeh et al., 2013). Formaldehyde emission from panels in service is caused by residual formaldehyde present in the UF bonded panels trapped as gas in the

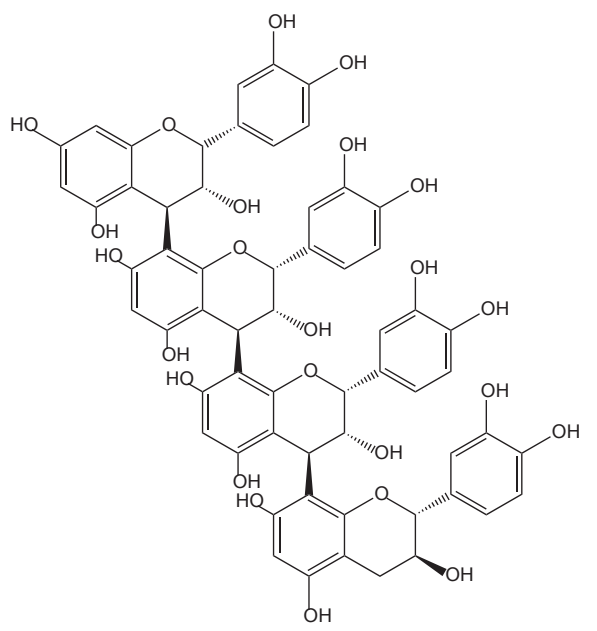

Figure 1 Condensed tannin

Slika 1. Kondenzirani tanin

structure and formaldehyde dissolved in the water present in the boards (Aydin et al., 2006; Doosthoseini, 2002). UF is water based wood adhesive whose shortcomings are low efficiency, poor water resistance and formaldehyde emission (Doosthoseini, 2002). Due to similar reasons, other water-based adhesives, including protein and starch based adhesives, are also not effective to bond directly grass-based particleboards (Roumeli et al., 2010)

Recently, there has been an interest in using tannin-based resins due to the more widespread availability of tannins, and the lower cost of tannin-based resins compared to CNSL. Tannins (Fig. 1) are naturally occurring phenolic compounds, which have been the subject of extensive research leading to the development of a wide range of industrial applications. The term "tannin" comes from the ancient Celtic word for oak, which still remains a popular source for tannins used in converting animal skin into leather (tanning). The objective of this study was to investigate the suitability of using natural tannins as an alternative to formaldehyde in urea and melamine formaldehyde resins used in MDF construction and to test the mechanical and physical properties of panels to determine if they have the required properties for general use.

\section{MATERIAL AND METHODS} 2. MATERIJAL I METODE

The raw material of this study included industrial wood fibers provided by a commercial fiberboard plant in Sari, Iran and tannin that was purchased from Merck, Germany. Thickness of panels was controlled by 
....... Sepahvand, Doosthosseini, Pirayesh, Maryan: Supplementation of Natural Tannins...

Table 1 Experimental design

Tablica 1. Osnovni parametri eksperimenta

\begin{tabular}{|c|c|c|c|c|c|c|c|}
\hline $\begin{array}{c}\text { Panel type } \\
\text { Vrsta ploče }\end{array}$ & $\begin{array}{c}\boldsymbol{W S} \\
\mathrm{wt. \%}\end{array}$ & $\begin{array}{c}\boldsymbol{M F} \\
\mathrm{wt.} \%\end{array}$ & $\begin{array}{c}\boldsymbol{T}_{10 \%} \boldsymbol{M F} \\
\text { wt.\% }\end{array}$ & $\begin{array}{c}\boldsymbol{T}_{20 \%} \boldsymbol{M F} \\
\text { wt.\% }\end{array}$ & $\begin{array}{c}\boldsymbol{T}_{10 \%} \boldsymbol{U} \boldsymbol{F} \\
\text { wt.\% }\end{array}$ & $\begin{array}{c}\boldsymbol{T}_{20 \%} \boldsymbol{U} \boldsymbol{F} \\
\text { wt.\% }\end{array}$ & $\begin{array}{c}\text { Temperature press } \\
\text { Temperatura prešanja } \\
{ }^{\circ} \mathrm{C}\end{array}$ \\
\hline $\mathrm{A}_{170}$ & 90 & 10 & - & - & - & - & 170 \\
\hline $\mathrm{A}_{180}$ & 90 & 10 & - & - & - & - & 180 \\
\hline $\mathrm{B}_{170}$ & 90 & - & 10 & - & - & - & 170 \\
\hline $\mathrm{B}_{180}$ & 90 & - & 10 & - & - & - & 180 \\
\hline $\mathrm{C}_{170}$ & 90 & - & - & 10 & - & - & 170 \\
\hline $\mathrm{C}_{180}$ & 90 & - & - & 10 & - & - & 170 \\
\hline $\mathrm{D}_{170}$ & 90 & - & - & - & 10 & - & 180 \\
\hline $\mathrm{D}_{180}$ & 90 & - & - & - & 10 & - & 170 \\
\hline $\mathrm{E}_{170}$ & 90 & - & - & - & - & 10 & 180 \\
\hline $\mathrm{E}_{180}$ & 90 & - & - & - & - & 10 & \\
\hline
\end{tabular}

Table 2 Production parameters of MDFs

Tablica 2. Parametri proizvodnje MDF ploča

\begin{tabular}{|l|c|}
\hline Parameter / Obilježje & $\begin{array}{c}\text { Value } \\
\text { Vrijednost }\end{array}$ \\
\hline Pressing time / Vrijeme prešanja, min & 7 \\
\hline Peak pressure / Tlak prešanja, $\mathrm{kg} / \mathrm{mm}^{2}$ & 35 \\
\hline Thickness / Debljina, $\mathrm{mm}$ & 12 \\
\hline Dimensions / Dimenzije, $\mathrm{mm}$ & $420 \times 420$ \\
\hline $\begin{array}{l}\text { Number of panels for each type } \\
\text { Broj proizvedenih ploča za svaki tip ploče }\end{array}$ & 3 \\
\hline
\end{tabular}

stop bars and panels target density was $0.7 \mathrm{~g} / \mathrm{cm}^{3}$. Three panels were produced for each group. The experimental design is shown in Table 1.

The dimensions of the produced panels were $42 \times$ $42 \times 1.2 \mathrm{~cm}$. The produced MDF panels were conditioned at $20{ }^{\circ} \mathrm{C}$ and $65 \%$ relative humidity to reach moisture content of about $12 \%$ before trimming to final dimension of $40 \times 40 \times 1.2 \mathrm{~cm}$. The panel production parameters are also displayed in Table 2.

Some mechanical properties: modulus of rupture $(M O R)$, modulus of elasticity (MOE) (EN 310), internal bond strength $(I B)$ (EN 319), and physical properties: thickness swelling (TS) and water absorption $(W A)$ were determined for the produced fiberboards (EN 317). The average of 10 and 20 measurements were reported for mechanical and physical properties, respectively. The formaldehyde emission of the samples was measured according to the EN 717-3 standard. Six sheets of test pieces (with dimensions of $12 \times 25 \times 25$ $\mathrm{mm}$ ) were clamped $40 \mathrm{~mm}$ above water level using a plastic support in a $500-\mathrm{ml}$ polyethylene bottle containing $50 \mathrm{ml}$ of distilled water. The flask containing the specimens was loaded in the oven at $40{ }^{\circ} \mathrm{C}$ for 180 min. Formaldehyde released from the specimens was absorbed by the distilled water, which was subsequently used as the sample solution. The formaldehyde concentration in the sample solution was determined using acetylacetone-ammonium acetate solution and the acetylacetone method, with colorimetric detection at $412 \mathrm{~nm}$. The data obtained was statistically analyzed using analysis of variance (ANOVA). Duncan's grouping was also included.

\section{RESULTS AND DISCUSSION} 3. REZULTATI I RASPRAVA

Table 3 shows the results of mechanical properties of produced MDF panels. The highest MOR (27.12 $\left.\mathrm{N} / \mathrm{mm}^{2}\right)$ and MOE $\left(2685 \mathrm{~N} / \mathrm{mm}^{2}\right)$ values were measured for fiberboard produced employing neat MF resin. Besides, the lowest MOR $\left(22.78 \mathrm{~N} / \mathrm{mm}^{2}\right)$ and $M O E$ $\left(2285 \mathrm{~N} / \mathrm{mm}^{2}\right)$ values were determined for panels type E, including $20 \%$ tannin in UF resin. The result indicated that, with increasing tannin content in the mixture, the $M O R$ and $M O E$ values of fiberboards significantly decreased. Statistical analysis found some significant differences $(P<0.01)$ between some group means for $M O R$ and $M O E$ values. Significant differences between groups were determined individually for these values by Duncan's multiple comparison tests. The results of Duncan's multiple range tests are shown in Table 3, denoted by letters. Depending on the amount of tannin content in the panels, average decreases in MOR values varied from $1.4 \%$ to $16.1 \%$ as compared to the average of the panel type A. All panel types showed significant differences $(P<0.01)$ from each other in their $M O R$ properties. $M O E$ values showed relatively similar trends to those of $M O R$. The average $M O E$ values of the panels with tannin content decreased from $10.4 \%$ to $14.9 \%$ as compared to values of the panels made with unmodified MF resin (panel type A). With the exception of panel types B and C, as well as D and E, other panel types showed statistically significant differences $(P<0.01)$ from each other in their $M O E$ properties. Addition of tannin content to panels had more adverse effect on $M O R$ than on $M O E$ values. The average $M O R$ values of all panel types met the minimum requirement $(22.78 \mathrm{MPa})$ of EN 622-5 for general-purpose MDF panels for use in dry conditions. However, only average $M O E$ values of the panel type A met the minimum requirements for general purpose MDF (2500 MPa) of EN 622-5.

IB values of the experimental panels ranged from 0.53 to $0.70 \mathrm{~N} / \mathrm{mm}^{2}$. The highest IB value was observed for panel A, while the lowest was recorded for $\mathrm{E}$ type panel. IB values decreased with the increasing tannin content in the panels. The average decreases of 
Table 3 Mechanical properties of MDF panels made from UF/tannin and MF/tannin and wood fibers and test results of ANOVA and Duncan's mean separation

Tablica 3. Mehanička svojstva MDF ploča proizvedenih od smjese UF/tanina odnosno MF/tanina i drvnih vlakanaca te rezultati testa ANOVA i Duncanova testa srednjih vrijednosti

\begin{tabular}{|c|c|c|c|c|c|c|c|}
\hline $\begin{array}{l}\text { Mechanical properties } \\
\text { Mehaničko svojstvo }\end{array}$ & $\begin{array}{l}\text { Panel type } \\
\text { Vrsta ploče }\end{array}$ & $\begin{array}{c}\text { Mean }^{\mathrm{a}} \\
\text { Srednja } \\
\text { vrijednost }\end{array}$ & $\begin{array}{c}\text { Std. deviation } \\
\text { Standardna } \\
\text { devijacija }\end{array}$ & $\begin{array}{c}\text { Std. error } \\
\text { Standardna } \\
\text { pogreška }\end{array}$ & $\boldsymbol{X}_{\mathrm{Min}}^{\mathbf{b}}$ & $X_{\operatorname{Max}}{ }^{c}$ & $p^{\mathrm{d}}$ \\
\hline \multirow{5}{*}{$\operatorname{MOR}\left(\mathrm{N} / \mathrm{mm}^{2}\right)$} & $\mathrm{A}$ & $27.12^{s}$ & 0.289 & 0.130 & 25.10 & 24.92 & $*$ \\
\hline & $\mathrm{B}$ & $26.75^{u}$ & 0.235 & 0.089 & 24.60 & 24.65 & $*$ \\
\hline & $\mathrm{C}$ & $25.19^{t}$ & 0.119 & 0.041 & 23.80 & 23.54 & $*$ \\
\hline & $\mathrm{D}$ & $24.45^{v}$ & 0.127 & 0.052 & 23.02 & 22.41 & $*$ \\
\hline & $\mathrm{E}$ & $22.78^{w}$ & 0.228 & 0.088 & 20.90 & 21.90 & $*$ \\
\hline \multirow{5}{*}{$M O E\left(\mathrm{~N} / \mathrm{mm}^{2}\right)$} & $\mathrm{A}$ & $2685^{\mathrm{s}}$ & 34.995 & 13.975 & 2480.00 & 2580.00 & $*$ \\
\hline & $\mathrm{B}$ & $2407^{u}$ & 13.754 & 5.545 & 2468.00 & 25200.00 & $*$ \\
\hline & $\mathrm{C}$ & $2395^{\mathrm{u}}$ & 33.389 & 13.980 & 2414.00 & 2490.00 & $*$ \\
\hline & $\mathrm{D}$ & $2412^{t}$ & 27.003 & 9.995 & 2348.00 & 2385.00 & $*$ \\
\hline & E & $2285^{t}$ & 11.680 & 4.855 & 2292.00 & 2376.00 & $*$ \\
\hline \multirow{5}{*}{$I B\left(\mathrm{~N} / \mathrm{mm}^{2}\right)$} & $\mathrm{A}$ & $0.70^{\mathrm{s}}$ & 0.028 & 0.011 & 0.59 & 0.66 & $*$ \\
\hline & $\mathrm{B}$ & $0.68^{\mathrm{s}}$ & 0.012 & 0.005 & 0.58 & 0.63 & $*$ \\
\hline & $\mathrm{C}$ & $0.62^{\mathrm{u}}$ & 0.018 & 0.007 & 0.54 & 0.60 & $*$ \\
\hline & $\mathrm{D}$ & $0.55^{\mathrm{u}}$ & 0.016 & 0.006 & 0.52 & 0.58 & $*$ \\
\hline & $\mathrm{E}$ & $0.53^{\mathrm{t}}$ & 0.014 & 0.005 & 0.50 & 0.53 & $*$ \\
\hline
\end{tabular}

${ }^{\mathrm{a}}$ Mean values are the average of 10 specimens. / Srednje vrijednosti dobivene su na temelju mjerenja provedenih na 10 uzoraka. ${ }^{\mathrm{b}}$ Minimum value / minimalna vrijednost; ${ }^{\mathrm{c}}$ Maximum value / maksimalna vrijednost;

d Significance level of 0.01 (for ANOVA) / razina značajnosti 0,01 (za test ANOVA).

$\mathrm{s,u,t,v,w}$ Values having the same letter are not significantly different (Duncan test). / Vrijednosti koje imaju isto slovo nisu statistickki signifikantno različite.

IB value, upon increasing the tannin content, were 12.9 $\%$ to $24.3 \%$ as compared to values of the panels made using neat MF resin (panel type A). With the exception of panel types A and B, as well as C and D, other panel types showed statistically significant differences $(P<0.01)$ from each other in their $I B$ properties. Out of the produced panels, only panel types $\mathrm{A}, \mathrm{B}$ and $\mathrm{C}$ met the $I B$ requirement $(0.60 \mathrm{MPa})$ of $\mathrm{EN} 622-5$ for general-purpose MDF panels for use in dry conditions.

The strength properties of wood products depend on many factors such as physical and mechanical properties as well as compact ratio of employed wood species, the configuration (orientation) and interfacial adhesion or interphase quality (Aydin et al., 2006; Ciannamea et al., 2010; Papadopoulos and Hague, 2003). Employed resin (bonder) plays a crucial role in wood based panels so that the quality of bonding, and hence the properties of the resulting materials, are dominantly determined by the type and quality of the bonder. There is close relationship between the ratio of urea and formaldehyde so that, with decreasing formaldehyde below a certain point, mechanical strength properties of the resulting UF resin will be seriously affected (Copur et al.,2008). Besides, chemical composition (lignin, cellulose and hemicellulose contents) of wood species has a strong influence on mechanical properties (Habibi et al., 2008) so that cellulose as well as hollocellulose contents have an impressive effect on surface wettability and hence adhesion (Aghakhani et al., 2013).

Unidirectional cellulose microfibrils constitute the reinforcing elements in the matrix blend of hemicellulose and lignin (Dunky and Pizzi, 2002). The effect of press temperature on mechanical properties of the resulting MDFs was not significant and this is why the result has not been included in the result and discussion part. The reason can be due to narrow temperature range used in this study.

Similar results have been published by different authors, who used various bio wastes (Aydin et al., 2006; Nemli and Colakoglu, 2005; Nemli et al., 2009). The results of ANOVA and Duncan's mean separation test for TS and WA of panels, made using the mixture of different adhesive formulations and wood fibers for 2 and $24 \mathrm{~h}$ water immersion times, are given in Table 4.

Adding tannin into MDF improved water repellency. With increasing tannin in the panels, the TS and WA values decreased from $3.3 \%$ to $33.1 \%$ and $4.5 \%$ to $21.8 \%$ for $2 \mathrm{~h}$ water immersion time, respectively. Likewise, for $24 \mathrm{~h}$ water immersion time, these figures were $3.4 \%$ to $14.7 \%$ and $2.1 \%$ to $17.1 \%$, respectively. The average TS values of all panel types showed significant difference $(P<0.01)$ from each other with the exception of panels D and E in TS after $2 \mathrm{~h}$ water immersion time. Besides, average WA values of all panel types showed significant difference $(P<0.01)$ from each other after 2 and $24 \mathrm{~h}$ water immersion time. TS values of all panels did not meet maximum property requirements of $15 \%$ for $24 \mathrm{~h}$ water immersion for general purpose MDF panels specified by EN 622-5 (2005) standard.

The water resistance properties of wood based composites are affected by both water uptake capacity of lignocellulosic raw material and adhesive bonding quality (Roumeli, et al., 2010). The effect of press temperature on physical properties of the resulting MDFs was not significant and this is why the result has not been included in the result and discussion part. The reason can be due to narrow temperature range used in this 
Table 4 Test results of thickness swelling (TS) of MDF panels produced from UF/tannin and MF/tannin and wood fibers and of ANOVA and Duncan's mean separation

Tablica 4. Bubrenje u debljinu MDF ploča proizvedenih od smjese UF/tanina odnosno MF/tanina i drvnih vlakanaca te rezultati testa ANOVA i Duncanova testa srednjih vrijednosti

\begin{tabular}{|c|c|c|c|c|c|c|c|c|}
\hline $\begin{array}{l}\text { Physical properties } \\
\text { Fizikalno svojstvo }\end{array}$ & $\begin{array}{l}\text { Panel type } \\
\text { Vrsta ploče }\end{array}$ & $\begin{array}{c}\text { Soaking time } \\
\text { Vrijeme } \\
\text { potapanja } \\
\text { min }\end{array}$ & \begin{tabular}{|} 
Meana $^{a}$ \\
Srednja \\
vrijednost
\end{tabular} & $\begin{array}{l}\text { Std. deviation } \\
\text { Standardna } \\
\text { devijacija }\end{array}$ & $\begin{array}{l}\text { Std. error } \\
\text { Standardna } \\
\text { pogreška }\end{array}$ & $\boldsymbol{X}_{\mathrm{Min}}^{\mathrm{b}}$ & $X_{\text {Max }}{ }^{\mathrm{c}}$ & $p^{\mathrm{d}}$ \\
\hline \multirow{10}{*}{$\begin{array}{l}\text { Thickness swelling } \\
\text { bubrenje u debljinu } \\
\text { (TS) }\end{array}$} & A & 2 & $12.01^{\mathrm{s}}$ & 0.201 & 0.089 & 10.26 & 12.40 & $*$ \\
\hline & B & 2 & $11.63^{\mathrm{u}}$ & 0.525 & 0.195 & 10.20 & 11.65 & $*$ \\
\hline & $\mathrm{C}$ & 2 & $8.85^{t}$ & 0.354 & 0.112 & 10.06 & 11.05 & $*$ \\
\hline & $\mathrm{D}$ & 2 & $8.50^{\mathrm{v}}$ & 0.343 & 0.085 & 9.54 & 10.62 & $*$ \\
\hline & $\mathrm{E}$ & 2 & $8.10^{\mathrm{v}}$ & 0.338 & 0.124 & 9.65 & 9.58 & $*$ \\
\hline & $\mathrm{A}$ & 24 & $21.25^{\mathrm{s}}$ & 0.404 & 0.123 & 20.35 & 21.80 & $*$ \\
\hline & B & 24 & $20.52^{\mathrm{s}}$ & 0.352 & 0.135 & 19.67 & 21.30 & $*$ \\
\hline & $\mathrm{C}$ & 24 & $19.83^{\text {u }}$ & 0.235 & 0.068 & 18.54 & 20.52 & $*$ \\
\hline & $\mathrm{D}$ & 24 & $19.02^{\mathrm{t}}$ & 0.429 & 0.163 & 18.33 & 19.30 & $*$ \\
\hline & $\mathrm{E}$ & 24 & $18.12^{\mathrm{v}}$ & 0.295 & 0.095 & 16.63 & 18.30 & $*$ \\
\hline \multirow{10}{*}{$\begin{array}{l}\text { Water absorption } \\
\text { upijanje vode } \\
\text { (WA) }\end{array}$} & $\mathrm{A}$ & 2 & $25.80^{\mathrm{s}}$ & 0.358 & 0.224 & 25.60 & 26.16 & $*$ \\
\hline & $\mathrm{B}$ & 2 & $24.65^{\mathrm{u}}$ & 0.457 & 0.186 & 24.02 & 25.12 & $*$ \\
\hline & $\mathrm{C}$ & 2 & $23.62^{t}$ & 0.364 & 0.224 & 23.41 & 23.52 & $*$ \\
\hline & $\mathrm{D}$ & 2 & $21.36^{\mathrm{v}}$ & 0.428 & 0.163 & 21.39 & 22.36 & $*$ \\
\hline & $E$ & 2 & $20.18^{\mathrm{w}}$ & 0.309 & 0.096 & 20.01 & 20.56 & $*$ \\
\hline & A & 24 & $34.41^{\mathrm{s}}$ & 0.421 & 0.136 & 33.56 & 34.50 & $*$ \\
\hline & $\mathrm{B}$ & 24 & $33.68^{u}$ & 0.402 & 0.128 & 31.02 & 33.22 & $*$ \\
\hline & $\mathrm{C}$ & 24 & $31.48^{t}$ & 0.708 & 0.298 & 30.54 & 32.52 & $*$ \\
\hline & $\mathrm{D}$ & 24 & $29.36^{v}$ & 0.375 & 0.104 & 28.37 & 29.00 & $*$ \\
\hline & $E$ & 24 & $28.54^{\mathrm{w}}$ & 0.319 & 0.095 & 28.09 & 28.45 & $*$ \\
\hline
\end{tabular}

${ }^{a}$ Mean values are the average of 10 specimens. / Srednje vrijednosti dobivene su na temelju mjerenja provedenih na 20 uzoraka. ${ }^{\mathrm{b}}$ Minimum value / minimalna vrijednost $;{ }^{\mathrm{c}}$ Maximum value / maksimalna vrijednos $t ;{ }^{\mathrm{d}}$ Significance level of 0.01 (for ANOVA) / razina značajnosti 0,01 (za test ANOVA).

s,u,t,w,w Values having the same letter are not significantly different (Duncan test). / Vrijednosti koje imaju isto slovo nisu statistički signifikantno različite.

study. Similar results have been reported for different bio wastes (Aydin, et al., 2006; Kim and Kim, 2005).

\subsection{Formaldehyde emission}

\subsection{Emisija formaldehida}

The addition of Tannin into the panels significantly decreased formaldehyde emission value (Fig. 3.). Depending on addition of tannin in the panels, the formaldehyde emission values ranged from $15 \%$ to $35 \%$ lower than the panels made with neat MF resin. The minimum value of formaldehyde gas emission was measured for panels made with $20 \%$ tannin in melamine formaldehyde resin. To be specific, panel type $\mathrm{C}$ had the lowest formaldehyde emission value with $6.5 \mathrm{mg} / 100 \mathrm{~g}(35 \%$ less than panel type A), followed by panel type B (8.5 $\%)$, panel type D (9\%), panel type E (9.3\%), and finally panel type A (10.2 mg/100 g) (Fig. 3.).

The results showed that the free-formaldehyde emission values of MDF panel types (E and C) for E1 class met the requirement of maximum $8 \mathrm{mg} / 100 \mathrm{~g}$ (Aydin et al., 2006). The decrease in formaldehyde emission of MDF panels with increasing tannin can be attributed to the scavenging effect of tannin and its chemical bonds with formaldehyde (Aydin et al., 2006). The similar results were reported in previous studies (Ayrilmis et al., 2009; Nemli and Aydin , 2007).They reported that the decrease in formaldehyde emission values in the panels may be due to high amounts of polyphenolic extractives in bark, especially tannins (Lei et

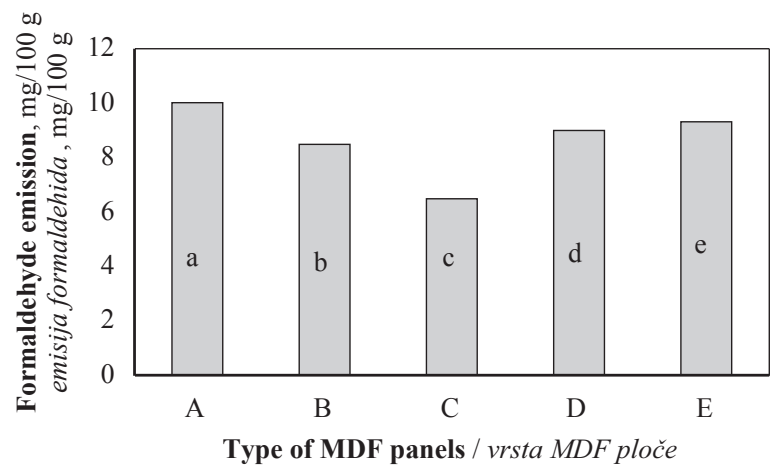

Figure 3 Percent decrease in average value of formaldehyde emission of panel types

Slika 3. Postotno smanjenje prosječne emisije formaldehida za sve vrste proizvedenih ploča

al., 2009). It was found that incorporation of mimosa bark particle greatly reduces formaldehyde emission of particleboards. Post-treatment methods, aimed at decreasing and minimizing formaldehyde release, are based on compounds like ammonia, ammonium salts, or urea (Nemli and Aydin , 2007). Another effective way to reduce formaldehyde release is the addition of formaldehyde-binding substances ("scavengers") to the resin or to wood particles (Aydin et al., 2006). Ammonium chloride acts as an acid catalyst of the curing reaction and as a formaldehyde scavenger (Kim, 2009). Coating panel surfaces with decorative overlays are to eliminate the 
release of formaldehyde (Lei et al., 2009). The environmentally friendly tannin-formaldehyde resins are among the cheapest binders and cause low-formaldehyde emission (Ayrilmis et al., 2009). Besides, processing conditions of wood based panels have a serious impact on relative formaldehyde emission so that the higher the press cycle time, the lower the formaldehyde emission at service (Aghakhani, 2013). It is to be noted that using nanoparticles, such as nano-Sio ${ }_{2}$ and nanoclay, due to their strong absorbability and high barrier properties (shielding effect) as formaldehyde catchers, will soon gain much attention (Kim, 2009; Papadopoulos and Hague, 2003).

\section{CONCLUSION 4. ZAKLJUČAK}

This study revealed that value-added MDF panels containing tannin can be considered as an alternative solution for decreasing carcinogenic gas of formaldehyde from wood based panels and for moving towards green chemistry. The incorporation of tannin greatly improved the formaldehyde emission of the panels; however, mechanical properties decreased with increasing tannin ratio. Using silane, dewaxing or raw material washing, the properties of wood based panels could be improved. Decreasing formaldehyde emission from MDFs containing tannin should be considered for furniture materials used indoor and this would be significant movement towards green chemistry and products.

\section{Acknowledgment - Zahvala}

The authors are grateful to the anonymous reviewers who provided useful comments to improve the clarity of the manuscript.

\section{REFERENCES}

5. LITERATURA

1. Abdolzadeh, H.; Doosthoseini, K.; Karimi, A. N.; Enayati, A. A., 2011: The effect of acetylated particle distribution and type of resin on physical and mechanical properties of poplar particleboard. Eur J Wood Prod, 69 (1): 3-10. https://doi.org/10.1007/s00107-009-0390-5

2. Aghakhani, M.; Enayati, S. H.; Nadalizadeh, H.; Pirayesh, H., 2013: The potential for using the sycamore (Platus orientalis) leaves in manufacturing particleboard. Int J Environ Sci Technol, 11 (2): 417-422. https://doi.org/10.1007/s13762-013-0327-8

3. Aydin, I.; Gursel, C.; Semra, C.; Cenk, D., 2006: Effects of moisture content on formaldehyde emission and mechanical properties of plywood. Building and Environment, 41 (10): 1311-1316. https://doi.org/10.1016/j.buildenv.2005.05.011

4. Ayrilmis, N.; Buyuksari, U.; Avci, E.; Koc, E., 2009: Utilization of pine (Pinus pinea L.) cone in manufacture of wood based composite. Forest Ecol Manage, 259 (1): 65 70. https://doi.org/10.1016/j.foreco.2009.09.043

5. Buyuksari, U.; Ayrilmis, N.; Avci, E.; Koc, E., 2010: Evaluation of the physical, mechanical properties and formaldehyde emission of particleboard manufactured from waste stone pine (Pinus pinea L.) cones. Bioresource Technology, 101 (1): 255-259.

https://doi.org/10.1016/j.biortech.2009.08.038
6. Ciannamea, E. M.; Stefani, P. M.; Ruseckaite, R. A., 2010: Medium-density particleboards from modified rice husks and soybean protein concentrate-based adhesives. Bioresource Technology, 101 (2): 818-825. https://doi.org/10.1016/j.biortech.2009.08.084

7. Copur, Y.; Guler, C.; Tascioglu, C.; Tozluoglu, A., 2008: Incorporation of hazelnut shell and husk in MDF production. Bioresource Technology, 99 (15): 7402-7406. https://doi.org/10.1016/j.biortech.2008.01.021

8. Doosthoseini, K., 2002: Wood composite materials, manufacturing, applications. Vol. 1 (Fundamentals). University of Tehran Press, Tehran, Iran [in Persian].

9. Dunky, M.; Pizzi, A.; 2002: Wood adhesives. In: Chaudhury, M.; Pocius A. V. (eds.) Adhesive science and engineering: surfaces, chemistry and applications, chap. 23. Elsevier, Amsterdam, pp. 1039-1103. https://doi.org/10.1016/B978-044451140-9/50023-8

10. Faruk, O.; Bledzki, A. K.; Fink, H. P.; Sain, M., 2012: Biocomposites reinforced with natural fibers: $2000-$ 2010. Progress in Polymer Science, 37 (11): 1552-1596. https://doi.org/10.1016/j.progpolymsci.2012.04.003

11. Habibi, Y.; El-Zawawy, W. K.; Ibrahim, M. M.; Dufresne, A., 2008: Processing and characterization of reinforced polyethylene composites made with lignocellulosic fibers from Egyptian agro-industrial residues. Compos Sci Technol, 68 (7-8): 1877-1885.

https://doi.org/10.1016/j.compscitech.2008.01.008

12. Khanjanzadeh, H.; Pirayesh, H.; Salari, A., 2013: Long term hygroscopic characteristics of polypropylene based hybrid composites with and without organo-modified clay. J Wood Sci, 71 (2): 211-218. https://doi.org/10.1007/s00107-012-0661-4

13. Kim, S., 2009: The reduction of indoor air pollutant from wood-based composite by adding pozzolan for building materials. Construction and Building Materials, 23 (6): 2319-2323. https://doi.org/10.1016/j.conbuildmat.2008.11.008

14. Kim, S.; Kim, H. J., 2005: Effect of addition of polyvinyl acetate to melamine-formaldehyde resin on the adhesion and formaldehyde emission in engineered flooring. International Journal of Adhesion and Adhesives, 25 (5): 456461. https://doi.org/10.1016/j.ijadhadh.2005.01.001

15. Lei, H.; Du, G.; Pizzi, A.; Celzard, A., 2008: Influence of Nanoclay on Urea-Formaldehyde Resins for Wood Adhesives and Its Model. Journal of Applied Polymer Science, 109 (4): 2442-2451. https://doi.org/10.1002/app.28359

16. Nemli, G.; Aydin, A., 2007: Evaluation of the physical and mechanical properties of particleboard made from the needle litter of Pinus pinaster Ait. Ind Crops Prod, 26 (3): 252-258.

https://doi.org/10.1016/j.indcrop.2007.03.016

17. Nemli, G.; Colakoglu, G., 2005: Effects of mimosa bark usage on some properties of particleboard. Turkish Journal of Agriculture and Forestry, 29: 227-230.

18. Nemli, G.; Demirel, S.; Gümüokaya, E.; Aslan, M.; Acar, C., 2009: Feasibility of incorporating waste grass clippings (Lolium perenne L.) in particleboard composites. Waste Management, 29 (3): 1129-1131.

https://doi.org/10.1016/j.wasman.2008.07.011 https://dx.doi.org/10.1016/j.wasman.2008.07.011.

19. Nemli, G.; Yildiz, S.; Gezer, E. D., 2008: The potential for using the needle litter of Scotch pine (Pinus sylvestris L.) as a raw material for particleboard manufacturing. Bioresource Technology, 99 (4): 6054-6058. https://doi.org/10.1016/j.biortech.2007.12.044

20. Papadopoulos, A. N.; Hague, J. R. B., 2003: The potential for using Xax (Linum usitatissimum L.) shiv as a lig- 
nocellulosic raw material for particleboard. Industrial Crop and Products, 17: 143-147. https://doi.org/10.1016/S0926-6690(02)00094-8

21. Roumeli, E.; Pavlidou, E.; Papadopoulou, E.; Vourlias, G.; Bikiaris, D.; Paraskevopoulos, K. M.; Chrissafis, K., 2010: Synthesis, characterization and thermal analysis of Urea Formaldehyde/nanoSiO2 resins, Thermochimica Acta, 527: 33-39. https://doi.org/10.1016/j.tca.2011.10.007

22. Salari, A.; Tabarsa, T.; Khazaeian, A.; Saraeian, A., 2013: Improving some of applied properties of oriented strand board (OSB) made from underutilized low quality paulownia (Paulownia fortunie) wood employing nano$\mathrm{SiO} 2$. Industrial Crops and Products, 42: 1-9. https://doi.org/10.1016/j.indcrop.2012.05.010

23. Zheng, Y.; Pan, Z.; Zhang, R.; EI-Mashad, H. M.; Pan, J.; Jenkins, B. M., 2009: Anaerobic digestion of saline creeping wild ryegrass for biogas production and pretreatment of particleboard material. Bioresour Technol, 100 (4): 1582-1588.

https://doi.org/10.1016/j.biortech.2008.08.048

24. FAO, 2012: State of the World's Forests. Rome. www. fao.org.

25. *** 1993: BS-EN 310: Wood-based panels, determination of modulus of elasticity in bending and bending strength. Brussels (Belgium); European Committee for Standardization.

26. *** 1993: BS-EN 317: Particleboards and fiberboards, determination of swelling in thickness after immersion. Brussels (Belgium): European Committee for Standardization.

27. *** 1996: BS- EN 717-3: Wood-based panels. Determination of formaldehyde release. Formaldehyde release by the flask method.

\section{Corresponding address:}

SIMA SEPAHVAND, Ph.D. student

Department of Wood and Paper Science and Technology

Natural Resources Faculty

University of Tehran

IRAN

e-mail: seppahvand.s@ut.ac.ir 